\title{
アルミニウム黄銅復水器管のフジッボ付着下の粒界腐食
}

\author{
川辽允志*，永田公二**，須藤久治**，田部善一**，加户隆介***，橘高二郎*** \\ * 関西電力株式会社（現在, 栗田工業株式会社) \\ ** 住友金属工業株式会社技術研究所 \\ *** 北里大学水産学部
}

\section{Intergranular Corrosion Beneath the Attached Barnacle on the Aluminium Brass Condenser Tube}

\author{
Atsushi Kawabe*, Koji Nagata**, Kyuji Sudo**, Zenichi Tanabe**, \\ Ryusuke Kado*** and Jiro Kittaka*** \\ * Kansai Electric Power Co. (at present Kurita Water Industries) \\ ** Research Laboratory, Sumitomo Light Metal Industry \\ *** School of Fisheries Sciences, Kitasato Univ.
}

\begin{abstract}
Aluminium brass condenser tubes suffer from ring-like corrosion accompanied intergranular corrosion beneath the barnacle attached. Immersion tests of aluminium brass sheets with barnacles were performed under various conditions such as the alive condition of barnacle, seawater condition (aerobic or anaerobic) and immersion time in order to make clear the corrosion mechanism. Ring-like corrosion was likely reproduced in the specimens with dead barnacie and/or after death of barnacle regardless of seawater conditions. The intergranular corrosion process is considered as follows. 1) A barnacle dies. 2) Body is decomposed. 3) Oxygen inside the wall is comsumed. 4) Inside the wall anaerobic condition is formed. 5) Inside the wall sulphate reducing bacteria is grown. 6) Sulphate in the seawater is reduced to $\mathrm{S}^{2-}$ inside the wall. 7) $\mathrm{S}^{2-}$ is transferred to the contact edge between outer lamina of wall and outer lamina of basis. 8) A local cell between inside part of the wall (anode) and outside of the wall (cathode) is formed. 9) The anode area suffers intergranular corrosion peculiar to corrosion morphology by polluted seawater containing $\mathrm{S}^{2-}$.
\end{abstract}

Key words: intergranular corrosion, aluminium brass, condenser tube, barnacle, crevice corrosion, sulfide ion

\section{1. 緒言}

海水を泠却水とする復水器管として広く使用されてい るアルミニウム黄銅管にフジッボ等の大型污損生物が付 着し，その下流に执いてデポジットアタックが発生する ことは，はやくから報告されてきたが，最近になって粒 界腐食が経験されるよらになった。その例を Fig. 1 に 示すが，腐食はフジツボ直下で発生している。

* 干661 尼崎市若王寺 (Wakoji, Amagasaki, 661 Japan)

** 干455 名古屋市港区千年 3-1-12, (3-1-12, Chitose, Minato-ku, Nagoya, 455 Japan)

*** テ022-01 岩手県気仙郡三陸町 (Sanriku-cho, Kesen-gun, Iwate, 022-01 Japan)
異物付着下の腐食は 1923 年に Evans が濃淡電池に よると提唱1)して以来, 異物付着下の腐食機構として濃 淡電池説がそのまま引き継がれ，污染水による粒界腐食 以外には, フジッボ等の大型污損生物付着下での粒界腐 食は報告されていない。

こうした腐食が発生するようになったのは最近になっ て大型污損生物が付着するようになったためと考光られ る。その理由として次のような使用環境上の変化が挙げ られる。(1) 復水器管の生物污損対策として実施されて きた塩素処理が，規制のため十分に注入できなくなり， 生物付着が可能となった。（2）防食対策としての第一鉄 イオン注入によって管表面に鉄皮膜が形成され，銅合金 


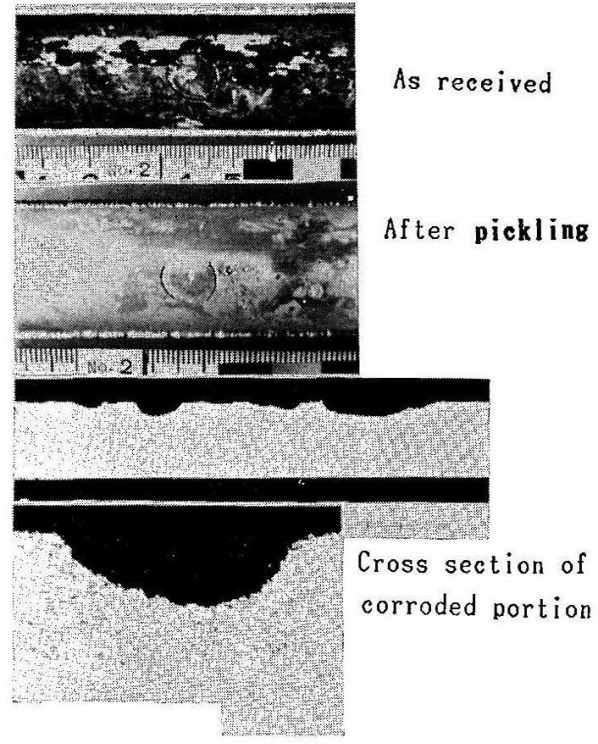

a) Ring like corrosion with pitting at the center.

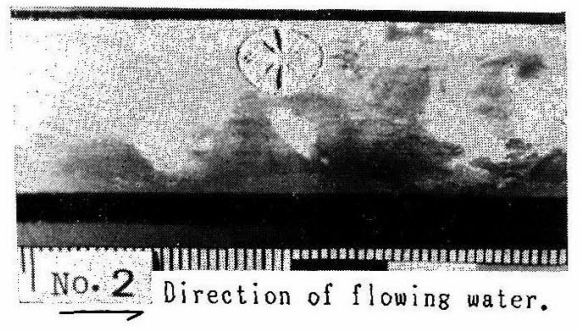

b) Ring like corrosion with radial groove

Fig. 1 Morphology of the ring-like corrosion under the barnacle, on aluminium brass condenser tube in-service.

の生物付着防止特性が陻蔽される傾向にあり, 生物が付 着しや寸くなった。(3) 火力発電所の起動停止の増加に より，管内冷却水水流の停止の機会加増加し，そのとき に生物が付着できることになった。

フジツボ付着に関連する属食作用としては次のるのが 考光られる。

1）流体剪断応力の増大によるフジッボ周辺の保護皮 膜の破壊

2) フジッボ付着部に扣ける酸素あるいはイオンの濃 度の濃淡に上る電池の形成

3）フジッボの排泄物，分泌物によるフジッボ直下で の液性 $(\mathrm{pH}$, 酸, アンモ二ア) の変化

4）フジッボの死減による軟体部の分解に伴う嫌気的 状態での硫酸塩還元細菌の増殖，い执らイオンの生成

これらのらち 1) はフジッボ直下での現象ではなく， 単なる “固形物” 閉塞部下流でもみられる，いわゆるデ ポジットアタックである。
また，3）については，フジッボの排泄物は外套腔に 出されるが，蓋の開口部を通じて壳外に放出されるた め，その影響がフジッボ直下にまで及ぶとは考えられな い。底盤は炭酸カルンウムを主体とし，その下面には接 着剂としてキノン交錯結合蛋白といわれるセメント物 質 ${ }^{2)}$ が存在するが，これも液性を変化させるとは考光ら 枕い。したがって，残る 2）と 4）が本腐食に関与し ている题いが妇たれる。

アジッボ直下でのアルミニウム黄銅管の腐食形態玩 Fig. 1 に示したよらに極めて特異であって，フジッポ 付着部の輪郭に沿って輸状に侵食され，から粒界腐食を 伴う。輪状以外にもフジッボ底盤下で放射状あるいは中 心部で点状に粒界腐食を生じているケースるみられる。

こうした粒界腐食は硫化物污染水腐食 ${ }^{3)}$ にみられるも のであり，上記腐食作用中の 4）が最も深く関与してい るものと推定される。しかし硫化物の生成過程自体につ いては詳細な検討が行われていないので，本稿ではフジ ソボをアルミニリム黄銅板上に付着させたるのを種々の 条件下で試験し，兵の結果に基づき腐食機棈の考察を行 った。乘た2）の作用に上る腐食発生の有舆についても 検討を行った。

\section{2. フジツボの構造と付着形態}

タテジマフジッボの綐断面を模式的に示すと Fig. 2 のよらである。㪍は炭酸カルシウムからなる周殼と底盤 によって構成され, その内部に軟体部が存在する。軟体 部は上部の蓋板（楯板と背板）を界して流入する海水に

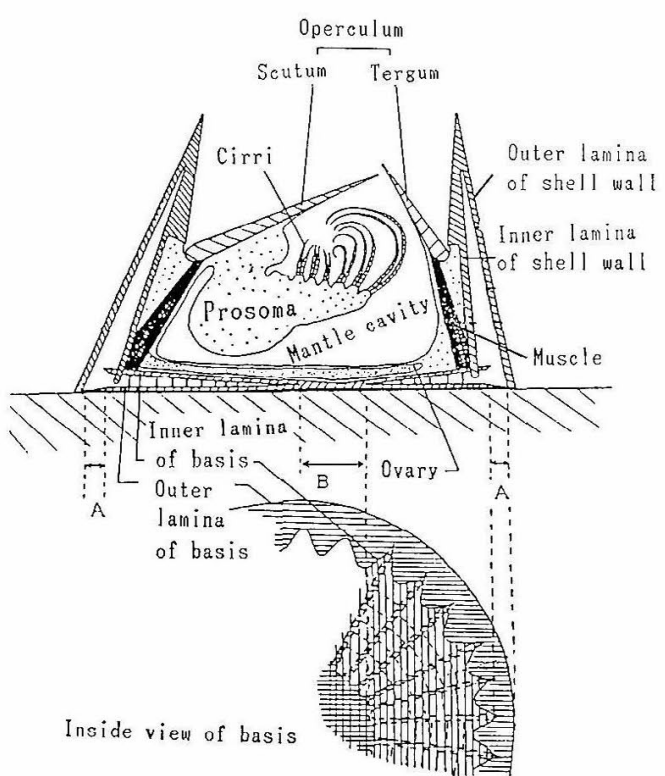

Fig. 2 Diagram of the structure of Balanus amphitrite. 


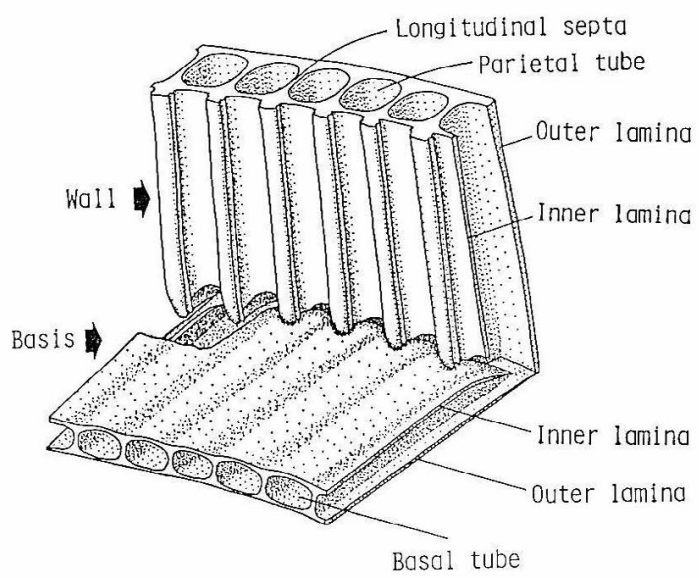

Fig. 3 Inner view of a piece of removed wall and basis in Balanus amphitrite.

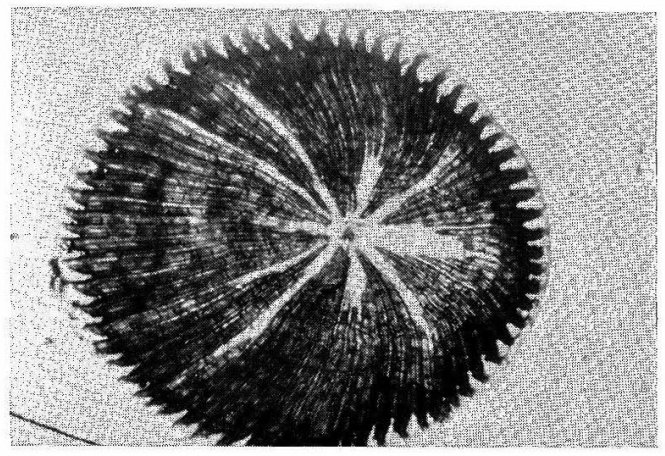

White radial parts don't exist basal tubes.

Fig. 4 Inner view of basis.

よって常に浸されている。周殼と底盤はともに Fig. 2， 3 に示すように内層と外層の二層の板が隔壁によってり ながった構造を示す。ただし底盤緣辺部では外層径がや や大きく, 周縁では厚さが薄くなっている (Fig. 2 のA)。 また底盤の中心部は付着初期に形成された部分であるた め，一層構造で厚さが薄い(Fig. 2 の B)。中心部以外 にもほかに放射状の一層構造の部分が存在する (Fig. 4)。したがって底盤では縁辺部及び中心部，放射状部に 炭酸カルシウムの厚さの薄い一層構造の部分が存在する ことになる。

周款と底盤の連結部においては, いずれの内層も鋸歯 状構造となり，雨内層が歯車のように啮みあった状態と なっているが，梌内層の哓み合わせ唍全ではなく隙間 が存在している (Fig. 3)。このことはフジッボが死隇し た際には殼内部の液状物がこの隙間を通して容易に底盤 縁辺部の一層構造の部分に到達しうることを示唆してい る。

フジッボ直下において，アルミニウム黄銅に生じた腐 食は，前述のように底盤縁辺部掞よび中心部，放射状部
に存在する一層構造の部分に対応するものと考えられ る。

\section{3. 㩐間腐食実験}

底盤は前述のようにセメント物質によって基盤に付着 しているが，わずかの隙間が存在して括り ${ }^{4)}$ ， ステンレ ス鋼等に拈いては，この部分で腐食することは辻川等に よって報告されている4)。一方，銅合金はこのような陌 間部での腐食は生じないといわれている。この点を確認 するためにテンロンとの人上隚間について海水浸漬実験 を行った。Fig. 5 に隙間の構成を示す。試料はアルミ ニウム黄銅と耐食アルミニウム合金（A-5052 O 材）で ある。77 日間天然海水に浸漬した後，テフロンシート

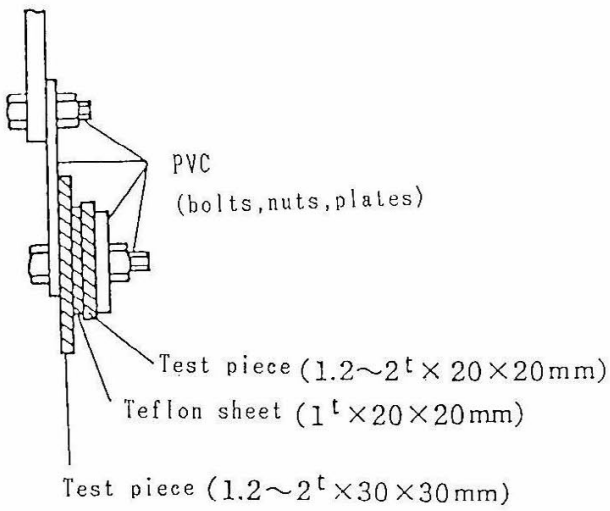

Fig. 5 Schematic illustration of the specimen for crevice corrosion test.

面を観察した。アルミニウム黄銅板面には腐食跡がみら れなかった。耐食アルミニウム合金には最大深さ 0.65 $\mathrm{mm}$ 火達する局部腐食がテフロンシート外周に近い箇所 にのみ発生し，テフロンシート接触面以外には顕著な局 部腐食は生じていなかった。

以上の結果からアルミニウム黄銅にはステンレスのよ らな隙間腐食の発生はないと一応結論付けられた。

\section{4. フジツボ直下での腐食実験}

\section{1 実験方法}

1984 年 5 月から 1.5 カ月間, $2.7 \times 7.6 \mathrm{~cm}$ のアル ミニウム黄鈳板を天然海水中に浸漬し，タテジマフジッ ボを付着させた。ついで試片上にできるだけ均一にフジ ソボが付着した状態になるように間引き，陸上水槽の流 水中で 9 月まで飼育した。

これらのフジッボを試片単位で Table 1 亿示寸 4 種 の状態に 調整し, 好気性と貧酸素性の 2 種の海水水槽 に 9 月 17 日に浸漬した。毎日 1 回アルテミア幼生を 給䭒したが，フジッボ死亡後はとりやめた。浸漬は 20 
Table 1 Test conditions

(a) Barnacles

\begin{tabular}{cccc}
\hline \hline \multirow{2}{*}{$\begin{array}{c}\text { Name of } \\
\text { Sample }\end{array}$} & \multicolumn{3}{c}{ Barnacles } \\
\cline { 2 - 4 } & Alive of dead & Body & Shell wall \\
\hline I & Alive & Exist & Exist \\
II & Dead* & Exist & Exist \\
III & Dead* $^{*}$ & Removed & Exist \\
IV & Dead* & Removed & Removed \\
\hline * Frozen to death at & $-20^{\circ} \mathrm{C}$. \\
(b) Sea water \\
\hline \hline Water tank \\
\hline Aerobic & Bubble air \\
Anaerobic & Remove oxygen* and cover the \\
\multicolumn{4}{c}{ water surface with plastics film } \\
\hline
\end{tabular}

* Bubble nitrogen gas and sodium sulfite

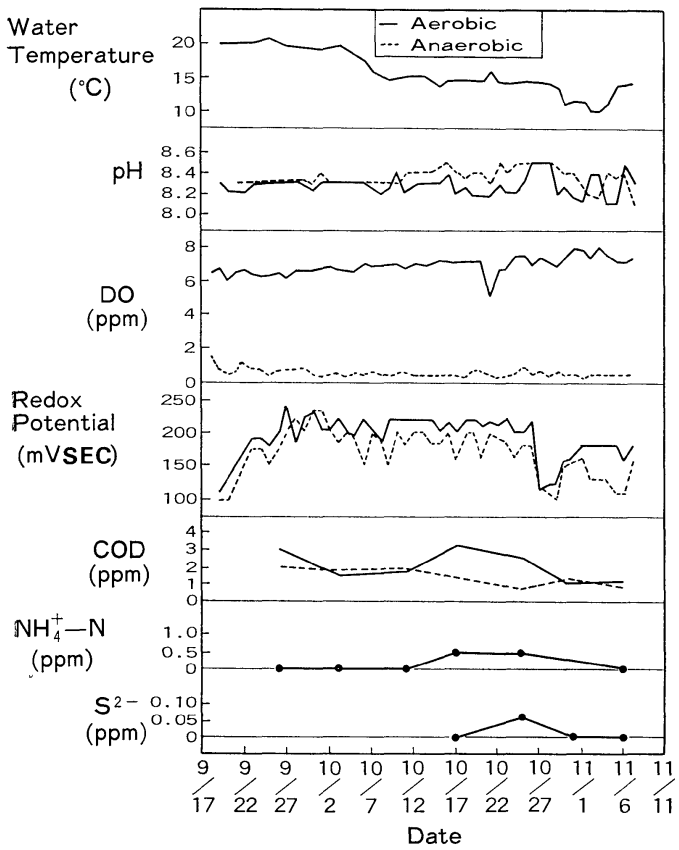

Fig. 6 Result of analysis of seawater in the water tanks.

日間と 60 日間としたが，その間適時海水を補給し， 20 日目，40日目には全量換水した。浸漬期間中水質 (DO, $\left.\mathrm{COD}, \mathrm{pH}, \mathrm{NH}_{4}{ }^{+}, \mathrm{S}^{2-}\right)$, 水温, 酸化還元電位を測定し た。

浸漬終了後試片を水槽から引き上げ, 直ちにフジツボ 殼内招よび周辺の $\mathrm{pH}$ 自然電位を測定した。自然電位の 測定には擬似マイクロチップを用いた。その後フジッボ をカッターナイフで取り除き, 試片表面及び取り除いた フジッボ 裏面を EDX 分析に供した。試片は酸洗し, スケール下部での腐食発生状態を観察した後, 代表的箅 所についてミクロ組織観察を行なった。

\section{2 結 果}

\subsection{1 暴露 環境}

水質測定結果を Fig. 6 亿示す。好気性水槽の海水の $\mathrm{DO}$ は $5 \sim 8 \mathrm{mg} / l$, 貧酸素性水槽の $\mathrm{DO}$ 恰徐々に低下乙, 10 日目以降はほぼ $0.2 \sim 0.6 \mathrm{mg} / \mathrm{l}$ であった。水温は 10 $\sim 21^{\circ} \mathrm{C}, \mathrm{pH}$ は $8.0 \sim 8.5$, COD $20.6 \sim 3.2 \mathrm{mg} / l$, $\mathrm{NH}_{4}{ }^{+}-\mathrm{N}$ は $0.01 \sim 0.46 \mathrm{mg} / l$ で, これらは両水槽に差 異はなかった。酸化還元電位は好気性水槽では初期（換 水直後も) $110 \mathrm{mV}$ で, 先の後 $240 \mathrm{mV}$ まで増加, 貧酸 素性水槽では好気性水槽より $20 \sim 30 \mathrm{mV}$ 高い值を示し たが，大きな差とはいい難かった。 $\mathrm{S}^{2-}$ は一時期を除き $0.02 \mathrm{mg} / l$ 以下で, 清浄海域での值と同程度であった。

\subsection{2 暴露中のフジツボの状況}

貧酸素性水槽では，DO が $1 \mathrm{mg} / l$ 以下に低下した 3 日目にフジッボが死亡した。好気性水槽でる 35 日目で 全部死亡した。

\subsection{3 暴露終了直後のフジツボ殼内及び周辺の $\mathrm{pH}$}

フジッボ殼内および周辺の $\mathrm{pH}$ は最低でも 5.8 であ り，腐食に影響するほどの $\mathrm{pH}$ の变化は認められなか った。

\subsection{4 暴露終了直後のフジツボ殸内及び周辺の電位}

フジッボ殼内拈よび周辺の自然電位は $-0.16 \sim-0.30$ VSCE であったが，殼内とフジッボ非付着部との間に は大きな差はなく，銅合金の海水中での自然電位として 普通のものであった。

\subsection{5 暴露終了後の外観}

試片表面は全体に黄褐色〜灰褐色を呈していた。各試 片には 2 15 個のフジッボが付着して和り，その大き さは最大で径 $9.5 \mathrm{~mm}$, 高さ $5.5 \mathrm{~mm}$ であったが, 大半 のものは径 $5 \sim 8 \mathrm{~mm}$, 高さ $3 \mathrm{~mm}$ 前後の小型のもので あった。軟体部を残存させた試料に批いても蓋板の脱落 や軟体部の脱落が認められるものがあった。軟体部が殼 内に残っている場合には軟体部の色が黒灰色となり, 腐 敗臭がした。

\subsection{6 フジツボ剝離後の状況}

フジッボの裏面は白色を呈するものが多いが，外周に 近い箇所に輪状や点状に黒色を呈している場合も存在し た。この黒色模様は死亡した軟体部が存在している実験 区に多くみられた。この黒いスケールには Fig. 7 a) に 示すように底盤の主成分である $\mathrm{Ca}$ 以外に $\mathrm{Cu}$ と $\mathrm{S}$ が 強く検出され， $\mathrm{Cl}$ もかなり強く検出された。

上記の黒色模様がみられる場合に执いては，フジッボ の付着していた試片上, フジッボの周殼外層内側に相当 する部位に輪状に黒色スケールがみられ，黒色スケール の下部に白色スケールも生成していた。この場合，黒色 スケールにはFig. 7 b) に示すように $\mathrm{Cu}$ と $\mathrm{S}$ が強く 検出され，その下部の白色スケールには Fig. 7 b) に师 
Table 2. Occurrence rate of corrosion

Number of barnacles under wihch corrosion occurred Number of barnacles on the plate

\begin{tabular}{ccccc}
\hline \multirow{2}{*}{ Name of sample } & \multicolumn{2}{c}{ Aerobic } & \multicolumn{2}{c}{ Anaerobic } \\
\cline { 2 - 5 } & After 20 days & After 60 days & After 20 days & After 60 days \\
\hline I & $1 / 8$ & $\left(3 / 6^{*}\right)$ & $\left(3 / 14^{*}\right)$ & $\left(9 / 10^{*}\right)$ \\
II & $0 / 6$ & $4 / 7$ & $4 / 8$ & $5 / 12$ \\
III & $0 / 6$ & $0 / 7$ & $1 / 4$ & $1 / 4$ \\
IV & $1 / 9$ & $0 / 7$ & $0 / 13$ & $0 / 2$ \\
\hline
\end{tabular}

* All barnacles in these experimental lots were died during the experimental period
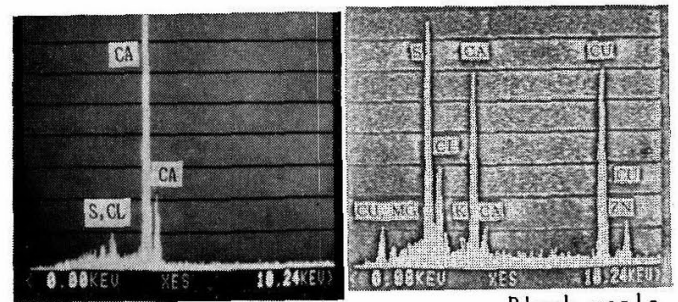

White scale

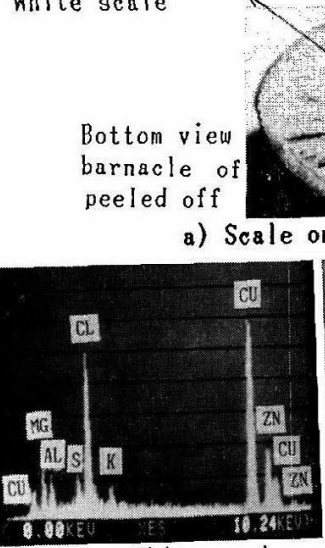

White scale (Inner scale) Black scale

b) Scale on the oorrosion

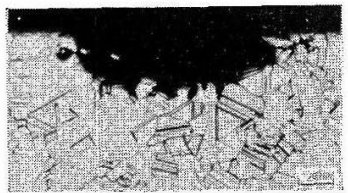

c) Microscopic photograph of corrosion pit

Fig. 7 Result of analysis of scale which corrosion occured and microscopic photograph of corrosion pit.

すように Cuと Cl が強く検出された。この場合，ス ケールを取り除くと，20日間浸漬試片では最大 0.05 mm, 60 日間浸漬試片で岕さらに進行して最大 $0.1 \mathrm{~mm}$ の深さに達する腐食が涩められ，いずれもFig. $7 \mathrm{c}$ ) K 示すよらな明らかな粒界腐食であった。

腐食発生状沙を Table 1 に示した契験条件ごと以整
理するとTable 2 が壳られた。本実験において, 貧酸素 性海水に設置した実験区では浸漬後数日で，ぬた好気性 海水に設置した実験区でも浸漬後 35 日までにフジッボ が死亡するにいたったため，好気性海水下 20 日間浸漬 の実験区そ除いて生存状態に括ける腐食の確認は行光な かった。生存フジッボによる腐食発生の有無については 別に，アルミニウム黄銅管を用いて央験を行い，管に付 着したフシッボを成長させたすのほついて生存を確認し たうえでフジッボを剥離し，腐食の発生の有無を調べた ところ，腐食は全く生じていないことが確認された。こ の事実からフジッボが生存中には腐食が起こらないるの と結論され，20日間好気性海水下で認められた 1 例の 腐食の存在は, 笑験終了時の生死の判別に問題があった ことが示唆された。

死亡させた軟体部の存在した笑跧区においては，実験 期間中に死亡した実験区 (Table 2 のカッユで示された 区）も含めて，20日閒浸漬では䞄酸素性海水に設置し た実験区に高頻度で腐食がみられたことから，腐食は貧 酸素性海水下で発生しやすいと考えられる。60日間浸 漬では好気性海水下でも高頻度で腐食が発生した。ただ 乙 Table 2 の分母の数字には実験期間中に軟体部が殼 外に脱落したものも含まれて和り，それらには腐食は発 生していたがた。

軟体部の存在しない実験区では3例の腐食が発生した が，これらは試験開始よりずっと以前に死亡し, 陸上水 槽に浸漬中に腐食を発生させていたものと推定される。

以上をとりまとめると次の上らになる。

フジッボ直下鹰食の発生条件:

一殼内に死亡した軟体部を含む，貧酸素性海水

一款内に死亡した軟体部を含む，好気性海水

フジッボ直下腐食の発生しない条件：

$\mid \begin{gathered}\text { 一ジッボが生存している } \\ \text { 一殼内に軟体部が存在しない（酸素の多寡に関係 } \\ \text { なし) } \\ \text { 一底盤のみ存在する(酸素の多宣に関係なし) }\end{gathered}$

腐食の発生とフジッボの大きさとの関係を検討した 
が，両者の間に相関は認められなかった。すなわち腐食 の発生は付着したフジッボの大小によるものでないと考 えられる。

\section{5. 考察}

フジッボを付着させたアルミニウム黄銅板を海水に浸 漬させたところ, 実際の復水器管に発生したと同じく, 周殼外層内側に輪状に粒界腐食を再現させることができ た。粒界腐食部の黑色スケールからは $\mathrm{Cu}, \mathrm{S}$ が強く検 出されたが，これは $\mathrm{Cu}_{2} \mathrm{~S}$ の生成によるものと考光られ る。このスケールは污染水通水下のアルミニウム黄銅管 に生成するスケールと同種のものであり，フジッボ直下 の周殼の内側が同様な環境になっていたことを示唆して いる。黑色スケールの下部に存在した白色スケールから は $\mathrm{Cu}, \mathrm{Cl}$ が強く検出されたが，これは $\mathrm{Cu}_{2}(\mathrm{OH})_{3} \mathrm{Cl}$ の生成によるものと考光られる。

しかもこのフジッボ付着直下での腐食はフジッボの死 亡による硫化物污染水腐食であって，フジッボが生きて いる間に生じる排泄物による腐食あるいは底盤下部での 吵間腐食ではないるのと考觉られる。

実際の復水器管にみられる腐食現象は，たまたまフジ ツボが死滅して，軟体部が殼内に残留していた箇所限 って生じているのであらう。事実 1 本のアルミニウム黄 銅管に多数のフジッボが付着している場合でも，フジッ ボ直下に腐食が生じているの梳必ずしも多くない。

フジッボが死滅して軟体部が腐敗を始めると，まず好 気的分解が行われるが，殼内の酸素が消費されつくす と, 款外からの酸素の拡散は蓋板によって妨害されるこ ととも相まって嫌気的状態となり，殼内に存在する有機 物を利用して, 硫酸塩還元細菌が増殖し, 殼内の海水中 の $\mathrm{SO}_{4}{ }^{2-}$ を還元して $\mathrm{S}^{2-}$ を生成させる。軟体部の腐敗 にともなら硫酸塩還元細菌の増殖は擬似フジッボを使っ た実験で確かめた。

こうして生成した $\mathrm{S}^{2-}$ は殼内の海水中を拡散してい くが，最初に周殼外層内側の底盤縁辺部の炭酸カルシウ 厶の極めて薄い一層構造部分を侵し, 硫化物污染水腐食 を発生させるものと考兄られる。な技実際の復水器管で みられる輪状以外の放射状抒よび中心部点状の粒界腐食 そついても前述のようにそれらの部位に一層構造を示す 部分が存在するため, $\mathrm{S}^{2-}$ の金属面への浸透が容易飞進 行しやすいためであると考光られる。

本腐食に和けるアノード部は Fig. 8 亿示すように, 腐食発生位置から久てフジッボ直下部であり，アノード 反応としては初期の好気的状態では下記の (1) 式, 後期 の嫌気的状態では下記の (2) 式となる。他方カソード反 応はアルミニウム黄銅等銅合金の海水中を対象とする限 り，下記の (3) 式の酸素の還元反応であって，フジッボ

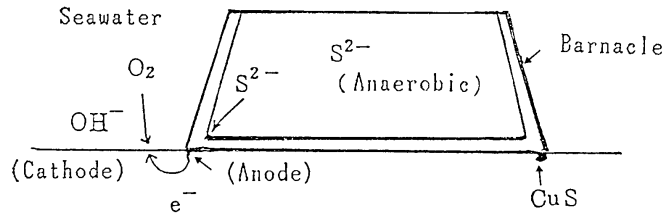

(Corrosion product)

Fig. 8 Corrosion model of aluminium brass beneath the barnacle.

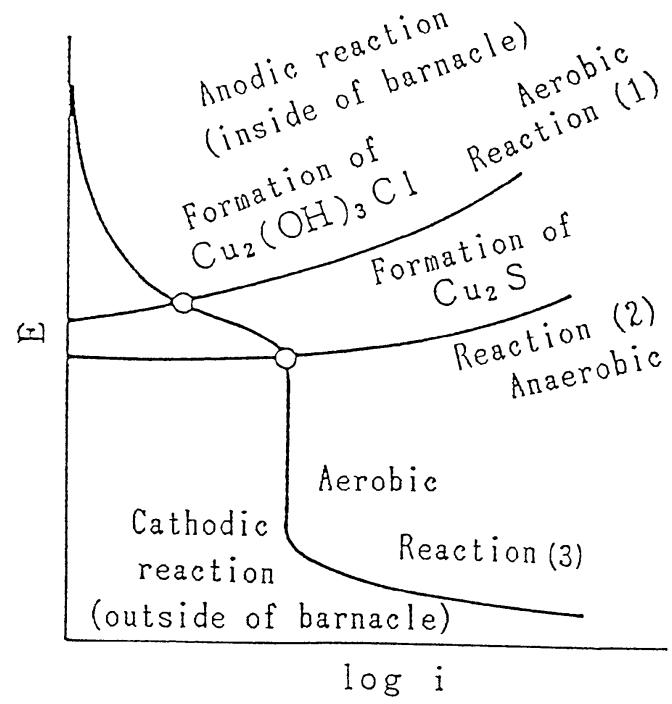

Fig. 9 Graphical presentation of corrosion reaction of aluminium brass in the anaerobic and aerobic conditions.

付着外側の周辺部で生じていると考える。

$$
\begin{aligned}
& \text { アノード反応 (フジッボ内 }) \\
& 2 \mathrm{Cu}+3 \mathrm{H}_{2} \mathrm{O}+\mathrm{Cl}^{-} \rightarrow \mathrm{Cu}_{2}(\mathrm{OH})_{3} \mathrm{Cl}+3 \mathrm{H}^{+}+4 \mathrm{e}^{-} \\
& 2 \mathrm{Cu}+\mathrm{S}^{2-} \rightarrow \mathrm{Cu}_{2} \mathrm{~S}+2 \mathrm{e}^{-} \\
& \text {カソード反応 }(\text { フジツボ外) } \\
& \mathrm{O}_{2}+2 \mathrm{H}_{2} \mathrm{O}+4 \mathrm{e}^{-} \rightarrow 4 \mathrm{OH}^{-}
\end{aligned}
$$

したがってフジッボ直下といら小さいアノードが，そ の周辺の大面積のカソードに取り囲をれるといった腐食 環境が形成されていることになる。そのため海水中に溶 存酸素が存在すれば，フジッボ内の $\mathrm{S}^{2-}$ が多いほど本腐 食反応は進行することになる。またカソード側での酸素 還元反応は拡散支配であって, 海水流動下で著しく加速 される。したがって海水流動下にある実機においては, 今回の静止浸漬状態よりもフジッボ直下腐食が, より加 速されるものと考兄らる。

しかし密閉に近いフジッボ内で生成される $\mathrm{S}^{2-}$ 量には 限界があるため, 腐食量も際限なく進行するとは考兄ら れない。実際穿孔事故の原因が本腐食であったとの報告 はみられず，今後も穿孔に至ることはないものと推察さ 
れる。

\section{6. 結 論}

フジッボを付着させたアルミニウム黄銅板の海水浸漬 実験により, 実際の復水器管のフジッボ直下に発生する ものと同じ粒界腐食を再現させることができた。さらに この腐食について次の点が明らかにされた。

1）周殼外層内側の底盤縁辺部の炭酸カルシウム層の 厚さの薄い部分に発生した粒界腐食は，フジッボが死亡 し, 殼内に軟体部が残存した場合に発生するものと推定 された。

2）腐食はフジッボ死亡後，ある期間経過後から発生 乙始め，腐食深さは時間とともに進行する傾向がみられ た。

3）腐食生成物から $\mathrm{S}, \mathrm{Cl}, \mathrm{Cu}$ が検出されたことか ら, $\mathrm{Cu}_{2} \mathrm{~S}, \mathrm{Cu}_{2}(\mathrm{OH})_{3} \mathrm{Cl}$ が生成したとみられた。

4）硫化物污染水型の腐食である。

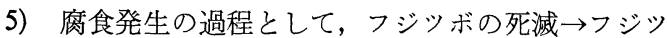
ボ殼内での軟体部の分解に上る溶存酸素の欠乏 $\rightarrow$ 嫌気的 状態の発生 $\rightarrow$ 硫酸塩還元細菌の増殖 $\rightarrow \mathrm{S}^{2-}$ の生成 $\rightarrow$ 周殼 外層内側底盤縁辺部への $\mathrm{S}^{2-}$ の拡散 $\rightarrow$ フシッボ下部を アノード，周殼外側をカソードとする局部電池の形成一 アノード部に $\mathrm{Cu}_{2} \mathrm{~S}$ の生成，が考えられる。

最後に本実験にあたって御協力, 御援助を賜った関係 各位に深謝します。

(Received June 9，1987)

\section{文献}

1) U. R. Evans: J. Inst. Metals, 30, 239 (1923).

2）加戸隆介：“フジツボ類の生活史”, p. 31, 電化海 生懇 (1983).

3）佃 俊雄，川辺允志：火力原子力発電， 25, 985 (1974).

4）辻川茂男，柴田俊明，篠原 正：防食技術， 33, 454 (1984). 